\title{
Acquiring English in EFL Classroom: Role of Literature
}

\author{
Md. Momin Uddin ${ }^{1}$ \\ ${ }^{1}$ Associate Professor, Department of English, Jagannath University, Bangladesh \\ Correspondence: Dr. Md. Momin Uddin, Jagannath University, Dhaka-1100, Bangladesh. E-mail: \\ momin.jnu7100@gmail.com
}

Received: October 24, 2018 Accepted: November 26, 2018 Online Published: January 24, 2019

doi:10.5539/ells.v9n1p17 URL: https://doi.org/10.5539/ells.v9n1p17

\begin{abstract}
This paper deals with how English literature can help EFL learners acquire English like ESL speakers. EFL learners usually learn English by learning its vocabulary and grammatical rules from books. ESL speakers, on the other hand, pick up the grammatical rules and vocabulary of English by directly getting into the environment where English is the medium of communication and acquire the language like the native. ESL speakers can speak English with native-like fluency and express their ideas in English like the native, but EFL learners, despite being capable of writing and speaking grammatically correct English, most often fail to speak with native-like fluency. Words seem to get stuck in their throats, and they often fumble and falter when speaking because their vocabulary remains poor in content. Nor can they express the true spirit of their ideas in their cultivated, grammatical English because they learn it in isolation without seeing how a native uses it. This paper argues that by studying English literature, EFL learners can grow awareness of the culture of the English and see how the English speak, feel, dream, and express their heart in English, and thus they can learn English like ESL speakers.
\end{abstract}

Keywords: literature, ELT material, EFL learners, acquiring English like L2 speakers

\section{Introduction}

The use of literature for teaching English had been in practice for years in the era of the Grammar-Translation Method. It was a trusted medium for students to learn grammar, vocabulary and the uses of words and phrases as it provided them with a huge body of authentic examples of sentence structures, verb conjugations, and uses of words and phrases. But in the mid 1900s when the focus of language teaching began to change giving emphasis on the development of students' communicative skills, the direct method and the audio-lingual method became popular, and both these methods neglected the role of translation process in language teaching. As a result, literature virtually disappeared from language teaching curriculums. The CLT experts sidelined literature on the ground that it taught mainly vocabulary and grammar through translation of texts from one language to another. Currently, some scholars are advocating the use of literature in the EFL teaching program, saying that literary texts in language classes can "provide rich linguistic input, effective stimuli for students to express themselves in other languages and a potential source of learner motivation" (British Council). This paper attempts to show how the use of literary texts can create a second-language-acquiring environment in the EFL classroom and help EFL learners acquire English in the way ESL speakers do.

\section{Literature Review}

Already a good number of research works have been done on the role of literature in language teaching classes. Analyzing these researches, two types of conflicting opinions are found regarding the use of literature in language teaching classes. While one group emphasizes the inclusion of literature courses in language teaching programs arguing that literary works present before learners authentic samples of the target language, give them opportunities to understand the culture of the target language community and help them get engaged in practicing the target language like the natives/L2 learners, the other group argues that even though literary works expose FL learners to the culture of the target language community and give them opportunities to see how the imaginary natives in literary works speak and communicate with others, the complexity of the language of literary works and the length of books often make it difficult for teachers to use them with the learners of different levels. Edmondson (1997) and Yuksel (2007) underestimate the role of literature to the development of second language competence and proficiency. On the other hand, scholars like Lazar (1993), Mckay (1982), 
Widdowson (1975), Parkinson and Thomas (2000), Shanahan (1997), Akyel and Yalcin (1990), Ghosn (2002) and many others favour the use of literature in language teaching classes arguing that literature provides all the basics that foreign language learners necessarily need to have to develop mastery over the target language. However, all these scholars of the essentialist group have talked about how literature can teach learners language in the foreign and L2 classroom. But my point of argument is different. I argue in this paper that English literary pieces chosen carefully and handled theoretically and methodically can contribute to the development of second language acquiring environment in the EFL classroom and thus can help EFL learners learn English with L2 competence and fluency. I also argue that English literature can be a good option for EFL learners to learn the totality of English - its vocabulary and their uses; its idioms, phrases and their uses; its structures and other grammatical rules and their uses; its pragmatics, stylistics and other unseen linguistic codes that can be learned intuitively only by being exposed to the native, natural environment of English.

\section{Pedagogy of Literature in ELT Classes}

\subsection{The Concept of Language}

Language is a medium of expression, a medium through which we express our ideas, feelings, emotions; a medium in which we think, we feel, we dream, we imagine, we laugh, we cry. Therefore, learning a language is actually acquiring a full capacity of doing all these in that language. A non-native can speak in a foreign language only by learning the meanings of words and phrases, and the grammatical rules of that language, but cannot perform the other activities mentioned above because one learns these activities intuitively and traditionally. Therefore, there remains a cultural gap in the speakers of a foreign language. Same is the case to EFL speakers. They speak English but their English sometimes fails to effectively communicate their ideas i.e. their English sometimes means either more or less than what they actually want to mean due to their lack of knowledge of the cultures of the English-speaking countries. To be able to effectively communicate in English, this cultural gap needs to be eliminated, and English literature can help eliminate this gap by exposing EFL learners to the culture of English societies since literature is a cultural product.

\subsection{The Concept of Literature}

Literature is actually a form of art in writing. These writings are different from other texts in that while other texts deal with realistic matters, literary texts are artistic and representational (McRae, 1994). McFadden (1978) defines literature as "a canon, which consists of those works in language by which a community defines itself through the course of its history. It includes works primarily artistic and also those whose aesthetic qualities are only secondary" (p. 56). According to Hirsch (1978), "literature includes any text worthy to be taught to students by teachers of literature ..." (p. 34). In this sense, even a poster that represents some social message is a literary piece. However, the popular concept of literature includes short stories, poems, novels, plays, folk tales, and song lyrics. All these genres can be used as 'langaids' in the ELT class.

\subsection{Relation of Language with Literature}

Like language, literature is also a medium of communication. Communicating some message to readers is one of the motives of an author behind writing a literary piece. Therefore, literature is communicative and interactive, and the means through which literature communicates and interacts with people is language. Language is the vehicle that carries what literature communicates to readers. Interesting thing is that when readers read a literary piece, they not only learn the story of the text but also get affected by the language of the text which is why it is found that people having read Shakespeare, Milton, Keats, Wordsworth, Byron, Browning, Eliot and the like speak a better language than those who have not read any literature. Persons having habits of reading literature are supposed to have rich vocabulary, and capacity of making brilliant sentences. Thus, literature itself is a resource of language. Much more language can be learned from literature if it is used as a resource for language teaching in the ELT classroom.

\subsection{Literature as a Linguistic Tool in ELT Classroom}

The primary function of literature when used as a linguistic input in a language class is that it offers opportunities to learners to practice the four language skills: reading, writing, speaking and listening, and to learn grammatical structures and uses of vocabulary. As literary texts are representational, learners can be engaged with the practice of speaking and writing by directing them to speak with their peers in the classroom on the meanings they make of the texts they read, and then by asking them to write their individual ideas of the texts. In various other ways, learners' speaking, writing and reading skills can be developed by using literary texts in a language class. Electronic records of poems, songs and stories can be helpful for learners to practice listening, speaking and writing in a language class. 
Another important reason for using literature as a tool for teaching English in the EFL classroom is that it provides learners with a huge body of written material manifesting both grammatical and semantic linguistic resources which help learners learn successfully all of what is meant by a language. It should be remembered that learning a language is not learning only the grammar and meanings of words and phrases of that language. The verbal signs of a language, along with expressing particular thoughts and ideas, also express the culture of the source language country, which is typical and can be learned only by being exposed to it. The grammatical rules and dictionaries teach only the meanings of words and phrases and their uses but fail to teach the pragmatics and cultural associations that the verbal signs of a language carry therewith which is why a grammatically correct speech is not always semantic and does not always suffice to communicate what is intended by verbal signs. Literature can bridge this gap between what grammar books and dictionaries fail to do and what learners actually need for meaningful communication.

After learning the grammatical structures and vocabulary of English language, learners are often faced with the problem of what to speak and write about with the help of the rules and vocabulary they have mastered. Literature, which offers a vast world of discussion, can engage learners with the various ideas and themes it deals with. While reading a literary piece, a learner can easily get involved into the multi-layered meanings and ideas of the text and can find lots of issues to discuss. Thus the use of a literary piece in an ELT classroom can engage learners and keep them engaged for long in the language learning activity — an activity the consistent practice of which can gradually make learners well conversant in the language.

To be able to express and communicate ideas in a language with comfort, easiness and spontaneity, apart from having sufficient vocabulary and knowledge of the grammatical structures of that language, what more one needs to have is knowledge of the pragmatics and cultural ethos of that language. Literature helps to develop this knowledge of a learner. Literature is a cultural product, and its language is representational rather referential (McRae, 1994). Referential language is not subject to be interpreted in various subjective ways by readers; it is informational and hence communicates only at one level while the representational language of literary texts represents various meanings to various readers of various merits. The understanding of a literary text involves the emotions, imagination, wit and intellect of learners, and thus literary texts can enhance the growth of the cognitive faculties of learners by engaging them psychologically and intellectually. Engaged with literary texts both psychologically and intellectually, learners can develop an understanding of the pragmatics and culture of the texts' language and can learn to think, feel and imagine in that language with its cultural ethos.

Along with learning the grammatical rules and vocabulary of a language, one needs to learn how a language functions and generates meanings. According to Collie and Slater (1987), a language functions both as a rule-based system and as a socio-semantic system. So one can learn the whole of a language only when s/he, after learning the rule-based system, is exposed to the socio-semantic system of the language. The rule-based system of a language can be learned by mastering the structural rules of the language, but the socio-semantic system of a language can be learned only by being exposed to the socio-cultural environment of the language. Collie and Slater (1987) suggest that literary texts help learners be exposed to the socio-semantic system of the language of the texts in the following ways:

- While reading a literary text, a student has to cope with the language intended for native speakers.

- In literary texts, foreign readers can discover the thoughts, feelings, dreams, emotions, customs, etc. of native speakers. Although the world presented in such texts is a created one, the different characters drawn in them from different social backgrounds are the representatives of their respective social classes. By reading such texts, a foreigner can feel as if s/he were in the country where the language of the texts is spoken.

- Literature generates personal involvement in readers, which facilitates the language learning process greatly. The regular engagement of learners in the world of literary texts makes the world with all its cultural and linguistic components familiar to them. When a reader explores a literary work over a period of time, the result is that the reader is drawn into the text and begins to feel like inhabiting it. This personal involvement of readers with literary texts helps the whole language learning process.

\subsection{Approaches to Using Literary Texts in Language Class}

To benefit from literature in the language classroom, both approaches to literature and methods of reading literature have to be chalked out carefully. According to Campbell (2007), lesson plans of the literature courses to be used as a resource for teaching language are to be formulated in such a way that they engage learners in the language learning process instead of engaging them to merely appreciate the literary value of the texts. To learn both the rule-based and the socio-semantic systems of a foreign language as well as to learn how to cope with 
that language psychologically, Carter and Long's (1991) models can be effective. Carter and Long suggested three models for reading literature in ELT classes, which are as follows:

1) Language Model: This model considers literature as a rich stock of linguistic features and draws students' attention to the grammatical, lexical and semantic aspects of a literary text.

2) Cultural Model: This approach views literature as a source of information about the culture of the society presented in the literature. Since having knowledge of the target language culture is necessary for learning the whole of that language, this approach can be helpful for learners to develop an understanding of the totality of the language.

3) Personal Growth Model: Reading literature makes its readers think, imagine and reflect. This psychological and intellectual involvement with the reading of literary texts in a language class develops students' ability of critical thinking, widens their stock of knowledge, and helps them be involved more actively in learning the language of the texts.

\subsection{Challenges of Using Literature in Language Classes}

Although literature can create an L2 acquiring environment in a non-native language class, both learners and teachers may face some challenges while using literature as a tool for teaching/learning language. Choosing the right model(s) is one of the challenges that teachers may face. It may vary from class to class and may depend on the intellectual level and age of learners. Sometimes integration of all the approaches, and sometime choosing one or two may be helpful.

Selecting the right course material for a particular class is also an important challenge. In this case, learners' age, interests and cognitive level need to be considered so that they feel eager to be engaged in reading the literary piece in use. An unusually long narrative or a piece written in too intricate language may not hold the attention of learners in a class. Again culturally offensive texts may be disliked by learners. English is now the native language of a number of countries, and this fact may pose a challenge to non-native ELT practitioners about which country's culture they should make their learners aware of to learn the totality of English language. Therefore, a careful selection of English texts, particularly those dealing with issues common to both English speaking countries and EFL countries, can serve the purpose effectively.

\subsection{Teaching Strategies to Be Improvised}

A teacher can improvise different strategies in the classroom to mentally prepare his/her learners to be engaged in the language learning process. The strategies should be so designed as to make the learners feel and think that the language to be used in the class is just the other language they know apart from their native language. To ensure an English language environment immediately after the teacher's entrance, s/he can exchange greetings, or can ask them some easy questions - like how are you all?, is it very hot toady, and the like - that everybody present can answer. Capacity of answering the teacher's questions in the language of the class can build up the confidence of learners and can help them get involved in the class activity actively and passionately. Once the language is on the tongue, students can communicate during the whole class hour in that language with ease and comfort. The class hour can be divided into three parts:

- Pre-reading session

- Reading session

- Post-reading session

Pre-reading Session: The pre-reading session can be used to mentally prepare the learners to take the class. In this session, the teacher can ask the learners only such questions or do with them such things that will, on one hand, create the target language learning environment and, on the other hand, involve the learners in the language learning process. This session can be called a warm up session and it may last for $5 / 6$ minutes. What is to be ensured importantly here is the participation and involvement of all learners together in responding to the teacher's approach. If any question is asked, it should be so tricky that even the most reticent student cannot sit idle but answer it.

Reading Session: A teacher may begin the reading session by inviting the learners to read out loudly some lines or the whole text of the literary piece to be used in the class. When all students read an English text loudly in a chorus, an English language environment is created in the class. The teacher may further engage the learners by asking them meanings of words, or names of words and phrases, synonyms of words; by asking them questions based on the text, which need to be answered with critical and intellectual involvement. 
Post-reading Session: In the post-reading session, a teacher may appreciate the learners' performance in the class activities, invite questions from the learners if they have any regarding the lesson, or may assign them with home-tasks of writing their experiences similar to what they have read in the text, and so on.

3.8 How to Use Literature in ELT Class - an Example

An example of how to use literature in a language class by following the above mentioned three approaches suggested by Carter and Long (1991) is given below: Suppose the following poem will be taught in an EFL class of $5^{\text {th }} / 6^{\text {th }}$ graders:

The Cow

(By Robert Louis Stevenson)

The friendly cow, all red and white,

I love with all my heart:

She gives me cream with all her might,

To eat with apple tart.

She wanders lowing here and there,

And yet she cannot stray,

All in the pleasant open air,

The pleasant light of day;

And blown by all the winds that pass

And wet with all the showers,

She walks among the meadow grass

And eats the meadow flowers.

\subsubsection{Example Activities according to Language Model}

Activity-1: Read the above poem and indentify which are naming words and which are describing words.

Activity-2: Identify the action words in the poem and make a sentence with each of them.

Activity-3: Match the following words in column A with their synonyms in column B.

\begin{tabular}{ll}
\hline Column-A & Column-B \\
\hline Cream & fair and comfortable \\
Might & an area of grassland \\
Apple tart & thick white or pale yellow fatty liquid \\
Wander & to move away from a group, \\
Stray & To move about without a definite destination or purpose \\
Pleasant & a small open pie filled with sliced apples and sugar \\
Wet & Strength \\
Meadow & soaked with water \\
\hline
\end{tabular}

3.8.2 Example Activities according to Cultural Model

Activity-1: Read the above poem and answer the following questions:

a) Does the poet talk about the whole cow species or only one particular cow in the poem?

b) Have you read any other poem by this poet?

c) What is a quatrain and how many quatrains are there in this poem?

d) How does the poem create musical sound?

e) Why does the poet love the cow? 


\subsubsection{Example Activities according to Personal Growth Model}

Activity-1: After reading the poem, think of the following:

- Does the poem encourage you to have a cow as your pet? How?

- Should we treat a cow sympathetically? Why.

- Do you have any pet? If yes, how much do you love your pet? How do you treat your pet? Does your pet love you as much as you do? How do you know that your pet loves you?

\section{Conclusion}

As a language is rooted in the contexts and culture of its speech community and as it works both as a rule-based system and as a socio-semantic system (Collie \& Slater, 1987), to acquire it, a foreigner, along with having mastery over its rule-based system, has also to understand its socio-semantic system. One can develop a fair understanding of the socio-cultural semantic codes of a foreign language by coming in contact with its native speakers. The target language literature can bring a foreign-language learner close to its native speakers. While reading a literary piece written in the target language, a foreigner can have the feel that $\mathrm{s} / \mathrm{he}$ is among the native speakers of the language, observing what they speak and how they speak. As literature provides authentic, representative language samples, foreign-language learners finding before them imaginary native speakers portrayed in the literature can acquire speech acts from them. Therefore this article suggests that EFL learners of all levels can acquire English easily and naturally like ESL learners, at least in the classroom, through rhymes, jokes, poems, stories, songs, role-plays based on stories and dramas, video-cliffs, etc. if these are used methodically with focus on language learning.

\section{References}

Akyel, A., \& Yalcin, E. (1990). Literature in the EFL class: A study of goal achievement incongruence. ELT Journal, 44(3), 174-180. https://doi.org/10.1093/elt/44.3.174

British, C. (n. d.). Using literature-an introduction. Teaching English. Retrieved from https://www.teachingenglish.org.uk/article/using-literature-introduction

Campbell, K. H. (2007). Less is more: Teaching literature with short texts, grades (pp. 6-12). Portland, Maine: Stenhouse Publishers.

Carter, R., \& Long, M. N. (1991). Teaching Literature. Harlow, Essex: Longman.

Collie, J., \& Slater, S. (1987). Literature in the language classroom. Cambridge: Cambridge University Press.

Edmondson, W. (1997). The role of literature in foreign language learning and teaching: some valid assumptions and invalid arguments. AILA Review, 12.

Ghosn, I. (2002). Four good reasons to use literature in primary school ELT. ELT Journal, 56(2), 172-179. https://doi.org/10.1093/elt/44.3.174

Hirsch Jr. E. D. (1978). What isn't literature? In P. Hernadi (Ed.), What is literature (pp. 24-34)? Bloomington: Indiana University Press.

Lazar, G. (1993). Literature and language teaching: A guide for teachers and trainers. Cambridge: Cambridge University Press. https://doi.org/10.1017/CBO9780511733048

McFadden, G. (1978). 'Literature': a many-sided process. In P. Hernadi (Ed.), What is literature (pp. 49-61)? Bloomington: Indiana University Press.

McKay, S. L. (2001). Literature as content for ESL/EFL. In M. Celce-Murica (Ed.), Teaching English as a second/foreign language (pp. 319-332). New York, NY: Heinle and Heinle.

McRae, J. (1994). Literature with a small 'l'. London: Macmillan Education

Parkinson, B., \& Thomas, H. R. (2000). Teaching literature in a second language. Edinburgh, UK: Edinburgh University Press.

Robert, L, S. (2008). The cow. A child's garden of verses. US: ReadHowYouWant Classic Library.

Shanahan, D. (1997). Articulating the relationship between language, literature, and culture: Toward a new agenda for foreign language teaching and research. The Modern Language Journal, 81(2), 164-74. https://doi.org/10.1111/j.1540-4781.1997.tb01171.x

Widdowson, H. G. (1983). Talking shop: Literature and ELT. ELT Journal, 37(1), 30-36. https://doi.org/10.1093/elt/37.1.30 
Widdowson, H. G. (1984). Stylistics and the teaching of Literature. London: Longman.

Yuksel, D. (2007). The nature of discussions in an advanced-level literature course in a Turkish EFL setting (Unpublished doctoral dissertation). Tallahassee: Florida State University.

\section{Copyrights}

Copyright for this article is retained by the author, with first publication rights granted to the journal.

This is an open-access article distributed under the terms and conditions of the Creative Commons Attribution license (http://creativecommons.org/licenses/by/4.0/). 